\title{
RNA Interference in Insect Vectors for Plant Viruses
}

\author{
Surapathrudu Kanakala and Murad Ghanim * \\ Department of Entomology, The Volcani Center, Rishon LeZion 7505101, Israel; kanakalavit@gmail.com \\ * Correspondence: ghanim@agri.gov.il
}

Academic Editor: Ralf Georg Dietzgen

Received: 5 December 2016; Accepted: 6 December 2016; Published: 12 December 2016

\begin{abstract}
Insects and other arthropods are the most important vectors of plant pathogens. The majority of plant pathogens are disseminated by arthropod vectors such as aphids, beetles, leafhoppers, planthoppers, thrips and whiteflies. Transmission of plant pathogens and the challenges in managing insect vectors due to insecticide resistance are factors that contribute to major food losses in agriculture. RNA interference (RNAi) was recently suggested as a promising strategy for controlling insect pests, including those that serve as important vectors for plant pathogens. The last decade has witnessed a dramatic increase in the functional analysis of insect genes, especially those whose silencing results in mortality or interference with pathogen transmission. The identification of such candidates poses a major challenge for increasing the role of RNAi in pest control. Another challenge is to understand the RNAi machinery in insect cells and whether components that were identified in other organisms are also present in insect. This review will focus on summarizing success cases in which RNAi was used for silencing genes in insect vector for plant pathogens, and will be particularly helpful for vector biologists.
\end{abstract}

Keywords: RNAi; dsRNA; plant viruses; insect vectors; insect pest control; virus induce gene silencing (VIGS)

\section{Introduction}

Insect vectors for plant pathogens are worldwide pests and pose a continuous threat to plants of economic importance. They vector bacteria and fungi and are responsible for the transmission of more than $70 \%$ of all known plant viruses [1]. The damage caused by plant viruses is estimated in the billions of dollars each year globally. The majority of insect vectors are controlled using chemical insecticides that threaten the environment, human health and beneficial organisms. More importantly, the development of insecticide resistance among many insect pests especially vectors for pathogens is a common problem. Therefore, the development of effective and non-chemical control methods against insect vectors is a major challenge. The development and use of genetically modified resistant plants have emerged as an important strategy that has proven to be important for the management of insect pests. Notably, two approaches have been developed: the first involves the use of transgenic plants expressing toxins from the bacterium Bacillus thurengiensis (Bt), and the second approach using plant-derived genes such as those that encode for inhibitors or lectins. However, many factors still limit these approaches to be fully successful such as: (a) Bt crops are not universal to all insect pests and are limited in their effectiveness against all insect; (b) sustainability; and (c) durability. Combining this with the increased ability of insect pests to develop resistance to all major insecticides including resistance to transgenic plants have facilitated the development of new methods for plant protection including RNAi-based protection.

RNAi is still considered as one of the most significant discoveries in biological research, and used for functional analysis of genes in eukaryotic organisms, including plants, mammals and insects. RNAi was first discovered in the worm Caenorhabditis elegans [2], in plants [3] and insects, first in the 
fruitfly Drosophila melanogaster [4]. The mechanisms and components of the RNAi machinery have been identified in many insect species including the functional analysis of genes in model and non-model insects [5,6]. During the last decade, many research projects have employed RNAi and made it possible to unveil the function of new genes and developed a new research discipline in which the development of pesticide-free control methods against insect pests became realistic. More importantly, recent results have suggested that insect vectors for plant pathogens bear the RNAi machinery as it was discovered in model organisms, leading to the hypothesis that vector-borne pathogens could be managed by silencing essential genes in the vectors either by interfering with the transmission or by killing the insect vector itself. Such approaches have not been employed for controlling vectors of plant pathogens, however more successful cases have been reported for suppressing essential genes that influence the insect fitness and fecundity [6]. The purpose of this review is to highlight successful cases in which RNAi was used for controlling or limiting populations of vectors of plant pathogens.

\section{Mechanism of RNA Interference in Insects}

RNA interference is a mechanism of post-transcriptional gene regulation in eukaryotes [7]. This process involves the synthesis of double stranded RNA (dsRNA) which is cleaved by the ribonuclease III type Dicer [8,9] into 20-25 bp small RNAs in an ATP dependent manner [3,10]. These small RNAs comprise three distinct groups, short-interfering RNA (siRNA, 19-24 nucleotides), microRNA (miRNA, 19-24 nucleotides), and piwi-interacting RNA (piRNA, 24-30 nucleotides). These fragments are assembled by Argonaute proteins to form a multi-protein RNA-induced silencing complex (RISC) that recognizes and targets the destruction of complementary gene or messenger RNA [11,12].

The effects of RNAi responses can be well categorized into, intracellular and extracellular RNAi. The intracellular RNAi involves the introduction of dsRNA into cells using delivery methods such as injection, transfection or electroporation directly into a cell. Extracellular RNAi involves delivery by injection, soaking or feeding [13-17]. The RNAi mechanism has been further categorized into two types: non-cell-autonomous and cell-autonomous. In cell-autonomous RNAi, the silencing process is limited to the cell in which the dsRNA is introduced [18]. Here, the dsRNA of the target gene is processed into 21-24 nt duplexes by RNase (Dicer) and then, these siRNAs are incorporated into RISC, which mediates mRNA degradation (Figure 1).

Non-cell-autonomous RNAi takes place mostly in multicellular organisms, for example, C. elegans [2]. This type involves an RNAi-mediated knockdown of the target gene expression at a different site from the production or application site of the dsRNA. There are two types of non-cell-autonomous RNAi: environmental RNAi and systemic RNAi. Environmental RNAi has been observed in a wide range of species, in which dsRNA is taken up by a cell from the environment. It was first discovered in Drosophila S2 cells [19-21]. Systemic RNAi Defective (SID-1) protein was shown to be involved in extending the silencing signal from the cell/tissue in which the dsRNA is applied to other cells/tissues [22]. SID-1 is essential and sufficient to mediate systemic spread of RNAi signal in both somatic and germ-line cells [23,24]. 


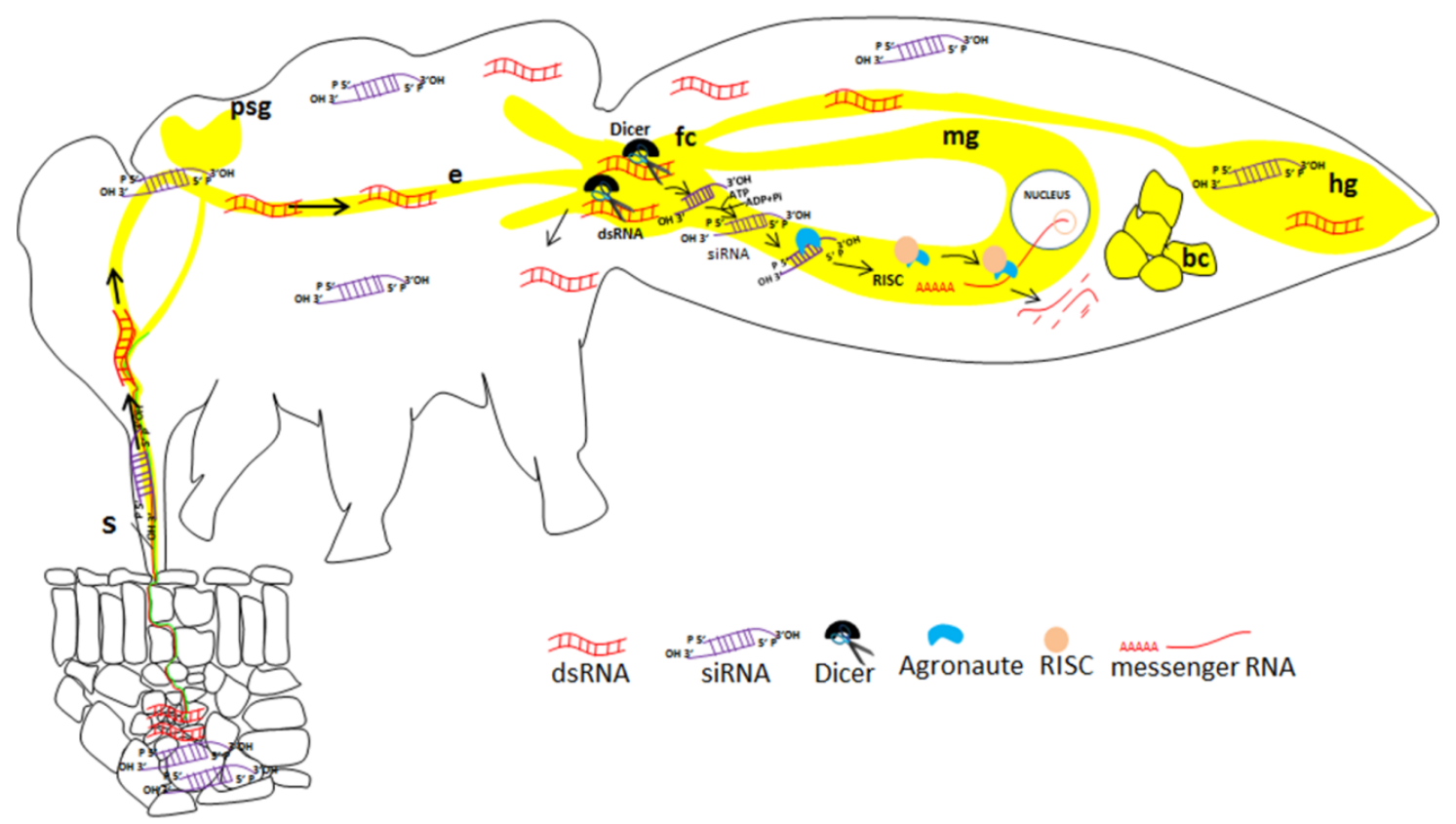

Figure 1. Illustration of gene silencing in a sap-sucking insect (Bemisia tabaci) by plant-mediated acquisition of siRNA. The siRNA molecules are acquired from the plant vascular tissue, move along the food canal and cross the midgut to the hemolymph, where they can reach many tissues in which silencing may be induced. The midgut is the first tissue in which efficient silencing may occur. S: stylet; psg: primary salivary glands; e: esophagus; fc: filter chamber; mg: midgut; hg: hindgut; bc: bacteriocyte.

\section{Delivery Methods of RNAi Molecules}

The success of an RNAi experiment depends upon the selection of: (1) target gene; (2) length range of dsRNA; and (3) delivery method. For efficient RNAi, target gene silencing should significantly influence the insect's fitness or cause mortality. The length of the target gene also influences the uptake and silencing efficiency. Efficient knockdown further depends on the concentration of dsRNA and delivery method. Several previous reports have proposed a size range between 50 and $520 \mathrm{bp}$ as the limit in inducing effective silencing [25-33]. Several previous studies have developed dsRNA delivery methods for introducing dsRNA into the insect hemocoel using microinjection with varying concentrations [34-38]. Other methods included feeding with dsRNA through artificial diet/oral delivery [39-41]; feeding with bacteria that expresses dsRNA [42], soaking in dsRNA [43]; nano-particle-mediated RNAi [44] and fungi expressing the specific dsRNA [45]. These methods were adapted for studying RNAi mechanisms in insects for research purposes, but none could be suggested as strategy for pest control under field conditions.

Engineering crops with insecticidal antimetabolic protein or plant derived genes toxic to insects can be an alternative defense strategy to control insect herbivory, growth, development and in some cases cause the death of the insect. It has been suggested that hairpin RNA (hpRNA) expressed in planta, were processed into siRNA by the plant Dicer and those siRNA were detected in the phloem sap of the transgenic plants [46,47]. There are three main approaches to obtain transgenic plants resistant to insects. The first involves the use of Bt delta-endotoxins, the second approach uses plant-derived genes, such as enzyme inhibitors or lectins [48,49], and the third involves plants expressing dsRNA/siRNA that target insect genes. Three approaches can be followed to generate such plants for silencing: (a) Stable transgenic plants expressing dsRNA $[14,15]$. The transgenic plants expressing specific dsRNA against insect genes have provided promising results, however none of these reached the level of commercialization for controlling insects under field conditions; (b) Virus induced gene silencing (VIGS) to transiently silence target genes of insects feeding on host plant [32,50]. In this regard, it was 
suggested that the phloem of virus-infected plants contains high level of siRNA [51]. This indicates that siRNA could be acquired by insects especially sap-sucking insects, following VIGS; (c) Spray of dsRNA on plants that could be acquired by the insects to induce silencing [43]. Developing such methods for the control of vectors of plant pathogens is scarce; however, VIGS and dsRNA spray have the potential to serve this goal.

\section{RNAi-Based Approaches for the Control of Insect Vectors}

To date, RNAi has been documented and studied in about thirty insect species that belong to nine insect orders [6]. Insect vector for plant pathogens can be found in seven of the 32 orders in the Insecta [52]. However, among these, sap-sucking insects that include aphids, whiteflies, hoppers, thrips and beetles are the major vectors that transmit the highest diversity and most important plant pathogens. For silencing in insect vectors, two approaches could be undertaken: one approach is silencing target genes for inducing mortality and controlling the insect population and the second is silencing that could lead to interference with the transmission. The cases that were reported in the different insect species will be summarized hereafter (Table 1).

\subsection{Aphids}

Aphids are the largest group of insects that transmit plant viruses and it is estimated that $28 \%$ of all plant viruses that belong to eight families, 18 genera, and some taxonomically unassigned viruses are transmitted by aphids [1,52]. RNAi has been successfully applied in aphids and silencing of aphid genes has shown significant effects on the insects such as mortality and reduction in fecundity.

The pea aphid Acyrthosiphon pisum is an important pest and transmits both non-persistent and persistent plant viruses [53]. In A. pisum, RNAi-mediated gene silencing was first shown by silencing the $\mathrm{C} 002$ gene [35]. Thereafter, other genes were targeted for silencing including C002, Mp10 and Mp42 [54], Calreticulin [36], vATPase [38], Aquaporin, ApAQP1 [40], gap gene hunchback (hb) [29], cathepsin-L [55], Angiotensin-converting enzymes (ACEs) [56], structural sheath protein (shp) [57], Peroxiredoxin 1 gene (ApPrx1) [58], macrophage migration inhibitory factor (MpMIF1) [59] and Cry $4 A a$ derived from B. thuringiensis subsp israelensis [60]. Among these, knockdown of C002 and Cathespsin-L vATPase, ACEs, MpMIF1 and shp genes showed significant mortality of A. pisum. 
Table 1. Reported cases of gene silencing in insect vector for plant pathogens.

\begin{tabular}{|c|c|c|c|c|}
\hline Organism & Targeted Genes & Delivery Method & Phenotype after Silencing & Reference \\
\hline Aphids & & & & \\
\hline \multirow{12}{*}{ Acyrthosiphon pisum } & Salivary protein $\mathrm{C} 002$ & Injection & Mortality & [35] \\
\hline & $\mathrm{C} 002, \mathrm{Mp} 10$ and $\mathrm{Mp} 42$ & Injection & Fecundity & [54] \\
\hline & Calreticulin & & - & [36] \\
\hline & vATPase & Artificial Feeding & Mortality & [38] \\
\hline & Aquaporin, $A p A Q P 1$ & Artificial Feeding & Elevate osmotic pressure of the hemolymph & [40] \\
\hline & hunchback $(h b)$ & Artificial Feeding & Higher mortality & [29] \\
\hline & cathepsin- $L$ & Injection/Artificial Feeding & Higher mortality and impaired molting & [55] \\
\hline & Angiotensin-converting $193 \mathrm{ACES}$ & Injection & Higher mortality & [56] \\
\hline & structural sheath protein $(\operatorname{sh} p)$ & Injection & Higher mortality & [57] \\
\hline & Peroxiredoxin 1 gene $(A p \operatorname{Pr} x 1)$ & Injection & decreased survival, increased oxidative stress & [58] \\
\hline & macrophage migration inhibitory factor (MpMIF1) & Injection & Decreased survival and fecundity & [59] \\
\hline & Cry 4 Aa derived from $B$. thuringiensis subsp israelensis & Artificial Feeding & Higher mortality & [60] \\
\hline \multirow{16}{*}{ Myzus persicae } & MpC002, MpRack1 & Tobacco and Arabidopsis & Reduced fecundity & [46] \\
\hline & Effector gene $\mathrm{MpC002,MpPIntO1 \text {and } M p P I n t O 2}$ & Tobacco and Arabidopsis & Reduced fecundity & [61] \\
\hline & serine protease $(M y S P)$ & Arabidopsis & Reduced fecundity & [62] \\
\hline & $\begin{array}{l}\text { Acetylcholinesterase } 2 \text { gene } M p A C h E 2 \text {; V-ATPase E; } 40 \text { ribosomal protein S5-like } \\
\text { isoform-1 Rps5; SWI/SNF-related matrix-associated actin-dependent regulator of } \\
\text { chromatin subfamily D member 1-like gene SMARCD1; tubulin folding cofactor D } \\
\text { gene } T B C D \text {; mediator complex subunit } 31 \text { Med31; ribosomal protein S14 Rps14 }\end{array}$ & Tobacco & Reduced fecundity & [63] \\
\hline & hunchback (hb) & & Reduced fecundity & [64] \\
\hline & Macrophage migration inhibitory factor $M p M I F 1$ & Artificial Feeding & Reduced fecundity & [59] \\
\hline & Aquaporin gene $M p A Q P 1$; sucrase gene $M p S U C 1$ and sugar transporter gene $M p S t 4$ & Tobacco & Reduced fecundity & [65] \\
\hline & \multirow{2}{*}{ Galanthus nivalis agglutinin, GNA } & Tobacco & insecticidal activity and higher resistance & [66] \\
\hline & & Potato & insecticidal activity and higher resistance & [67] \\
\hline & Allium sativum leaf lectin, $A S A L$ & Tobacco & insecticidal activity & [68] \\
\hline & Allium cepa agglutinin, $A C A$ & Mustard & insecticidal activity & [69] \\
\hline & Pinellia ternate agglutinin, PTA & Tobacco & insecticidal activity & [70] \\
\hline & Dioscorea batatas tuber lectin $1, D B 1$ & Tobacco & insecticidal activity & [71] \\
\hline & ConA & Potato & insecticidal activity & [72] \\
\hline & Helianthus tuberosus agglutinin, $H T A$ & Tobacco & insecticidal activity & [73] \\
\hline & NICTABA-related lectin, AtPP2 & Arabidopsis & insecticidal activity & [74] \\
\hline \multirow{4}{*}{ Myzus nicotianae } & ASAL & Tobacco & insecticidal activity & [75] \\
\hline & Zephyranthes grandiflora agglutinin, ZGA & Tobacco & insecticidal activity & [76] \\
\hline & Pinellia pedatisecta agglutinin, PPA & Tobacco & insecticidal activity & [77] \\
\hline & Sambucus nigra agglutinin, SNA-I' & Tobacco & insecticidal activity & [78] \\
\hline
\end{tabular}


Table 1. Cont.

\begin{tabular}{|c|c|c|c|c|}
\hline Organism & Targeted Genes & Delivery Method & Phenotype after Silencing & Reference \\
\hline \multirow{4}{*}{ Aphis gossypii } & CarE & Artificial Feeding & insecticidal activity & [79] \\
\hline & Cytochrome P450 monooxygenase gene CYP6DA2 & Cotton & insecticidal activity & {$[80,81]$} \\
\hline & odorant-binding protein $2(\mathrm{OBP} 2)$ & Cotton & impaired host-seeking and oviposition behavior & [82] \\
\hline & Amaranthus caudatus agglutinin (amaranthin) & Cotton & insecticidal activity & [83] \\
\hline \multirow{9}{*}{ Sitobion avenae } & $\begin{array}{l}\text { cytochrome } c \text { oxidase subunit VIIc precursor, zinc finger protein and } \\
\text { three unknown proteins }\end{array}$ & Wheat & High mortality & [84] \\
\hline & secreted salivary peptide $D S R 32$, salivary protein $D S R 33$, serine protease 1 DSR 48 & Artificial Feeding & High mortality & [85] \\
\hline & catalase $C A T$ & Artificial Feeding & Effect on its survivability & [86] \\
\hline & olfactory coreceptor gene SaveOrco & Artificial Feeding & lethality and induced wing morph differentiation & [87] \\
\hline & $A c e 1$ & Injection & Reduced fecundity & [88] \\
\hline & $\begin{array}{l}\text { cytochrome c oxidase subunit VII c precursor, secreted salivary peptide, salivary } \\
\text { protein } M Y S 2 \text { and serine protease } 1\end{array}$ & Artificial Feeding & High mortality & [85] \\
\hline & GNA-related lectin & Maize & reduction in nymph production & [89] \\
\hline & Carboxylesterase gene $\mathrm{CbE} \mathrm{E4}$ & Wheat & impaired tolerance to insecticides & [90] \\
\hline & Acetylcholinesterase gene Ace1 & Injection & impaired tolerance to insecticides & [88] \\
\hline Rhopalosiphum padi & Acetylcholinesterase gene Ace1 & Injection & susceptibility to insecticides & [88] \\
\hline \multirow{2}{*}{ Schizaphis graminum } & $\mathrm{C} 002$ & Artificial Feeding & Lethality & [91] \\
\hline & Pinellia ternate agglutinin, $P T A$ & Wheat & Insecticidal activity & [92] \\
\hline \multirow{3}{*}{ Lipaphis erysimi } & $\begin{array}{l}\text { Galanthus nivalis L. agglutinin, GNA, Allium sativum } \mathrm{L} \text {. leaf agglutinin, ASAL, } \\
\text { Allium cepa L. agglutinin, } A C A\end{array}$ & Mustard & insecticidal activity & {$[69,93]$} \\
\hline & wheat germ agglutinin, WGA & Mustard & insecticidal activity & [94] \\
\hline & Allium cepa $\mathrm{L}$. agglutinin, $A C A$ & Mustard & insecticidal activity & [69] \\
\hline Aulacorthum solani & Galanthus nivalis agglutinin, GNA & Potato & decreased fecundity & [95] \\
\hline \multicolumn{5}{|l|}{ Whiteflies } \\
\hline \multirow{8}{*}{ Bemisia tabaci } & Chickadee & Injection & Mortality & [37] \\
\hline & $\begin{array}{l}\text { ADP/ATP translocase, alpha-tubulin, ribosomal protein L9 (RPL9), and } \\
\text { Vacuolar-type ATPase A subunit }\end{array}$ & Artificial Feeding & Mortality & [96] \\
\hline & P450 CYP6M1 & Artificial Feeding & Increased mortality & [97] \\
\hline & v-ATPase A & Tobacco & Mortality & [98] \\
\hline & aquaporin, $A Q P$ and alpha glucodiase $(A G L U)$ & Tobacco & Mortality & [99] \\
\hline & Toll-like receptor 7 (TLR7) & Isaria fumosorosea & Increased mortality & [45] \\
\hline & Suppressing the terpenoid synthesis & tobacco & improved whitefly fitness and favored vector-virus mutualism & [100] \\
\hline & protein kinase (GhMPK3) & cotton & effects knockdown on eggs and pupa & [101] \\
\hline
\end{tabular}


Table 1. Cont.

\begin{tabular}{|c|c|c|c|c|}
\hline Organism & Targeted Genes & Delivery Method & Phenotype after Silencing & Reference \\
\hline \multicolumn{5}{|l|}{ Planthoppers } \\
\hline \multirow{27}{*}{ Nilaparvata lugens } & calreticulin, cathepsin-B, beta 2 & Injection & - & [102] \\
\hline & trehalose phosphate synthase, NITPS & Artificial Feeding & lethality & [41] \\
\hline & V-ATPase-E, 21E01 & ingestion & - & [103] \\
\hline & $\begin{array}{c}\text { hexose transporter gene } H T 1 \text {, the carboxypeptidase gene (CAR) and the trypsin-like } \\
\text { serine protease gene (TRY) }\end{array}$ & Rice & lethal phenotypic effects & [47] \\
\hline & NIFoxA & Artificial Feeding & effect on fecundity and development of ovaries & [104] \\
\hline & ecdysone & Artificial Feeding & phenotypic defects in molting and nymph lethality & [105] \\
\hline & coronatine insensitive1 (COI1) & rice & induced defenses & [106] \\
\hline & chitin synthases (CHS1 and CHS1a) & Injection & insect lethality & [107] \\
\hline & CHSb & Injection & increased mortality & [107] \\
\hline & flightin & Artificial Feeding & affected flight & [108] \\
\hline & Dicer $(d c r)$, Argonaute $(a g o)$, & Injection & severely impaired ecdysis & [109] \\
\hline & Dcr-2 & Artificial Feeding & no developmental changes & [110] \\
\hline & glutamine synthase (GS) gene & Injection & reduced fecundity & [111] \\
\hline & dicer1 & Injection & regulation of oogenesis in telotrophic ovary & [112] \\
\hline & Hsp 70 and Arginine kinase (Argk) & Artificial Feeding & survival & [113] \\
\hline & GSTe1 and GSTm2 & Injection & sensitivity of the fourth instar nymphs to chlorpyrifos & [114] \\
\hline & ecdysone receptor (EcR) & Artificial Feeding & reduced the survival rate of the offspring & [115]. \\
\hline & Vg receptor & Injection & fecundity & [116] \\
\hline & enolase gene (Eno1) & Injection & decreased egg lay & [117] \\
\hline & Bicaudal-C & Injection & role in oogenesis and oocyte maturation & [118] \\
\hline & acyl-coenzyme A oxidase $(A C O)$ & Artificial Feeding & decreased the reproduction and population growth & {$[119,120]$} \\
\hline & glutamine synthetase (GS) & Artificial Feeding/Injection & decreased the reproduction and population growth & [121] \\
\hline & NIHsp90 & Injection & reduced survival, role in thermotolerance & [122] \\
\hline & $\beta$-N-acetylhexosaminidase & Injection & failure of the nymphs to molt which eventually led to death & [123] \\
\hline & \multirow{2}{*}{ trehalose-6-phosphate synthases (TPS1 and TPS2) } & Injection & chitin metabolism and increased molting deformities and mortality rates & [124] \\
\hline & & Injection & regulates Vitellogenin synthesis and egg development & {$[125,126]$} \\
\hline & P450 proteins (CYP6AY1 and CYP6ER1) & Injection & imidacloprid resistance & [127] \\
\hline \multirow{5}{*}{ L. striatellus } & chitinase gene & Artificial Feeding & High mortality & [128] \\
\hline & Halloween gene Shade $(S h D)$ & Artificial Feeding & delayed nymphal growth and caused lethality & [129] \\
\hline & cytochrome P450 monooxygenase CYP353D1v2 & Artificial Feeding & sensitivity of L. striatellus to imidacloprid & [130] \\
\hline & Agronaute 2 & Injection & enhanced HiPV accumulation & [131] \\
\hline & cuticular protein (CPR1) & Injection & reducing the ability to transmit Rice stripe virus (RSV) & [132] \\
\hline
\end{tabular}


Table 1. Cont.

\begin{tabular}{|c|c|c|c|c|}
\hline Organism & Targeted Genes & Delivery Method & Phenotype after Silencing & Reference \\
\hline \multirow{6}{*}{ S. furcifera } & wingless gene & Artificial Feeding & shorter and deformed wings & [133] \\
\hline & disembodied (dib) & Artificial Feeding & nymphal growth and caused high mortality & [129] \\
\hline & Halloween gene phantom $(p h d)$ & Artificial Feeding & lethality and slower ecdysis during nymphal stages & [129] \\
\hline & ryanodine receptors ( $R y R 1$ and $R y R 2)$ & Artificial Feeding & decreased chlorantraniliprole-induced mortality & [134] \\
\hline & Halloween gene spook (spo) & Artificial Feeding & mortality & [135] \\
\hline & $P 7-1$ & Injection & southern rice black-streaked dwarf virus (SRBSDV) spread inside the insect & [136] \\
\hline \multicolumn{5}{|l|}{ Leafhoppers } \\
\hline \multirow{3}{*}{ Nephotettix cincticeps } & laccase-2 & Injection & high mortality & [137] \\
\hline & non-structural protein Pns10 & Injection & transmission of the Rice dwarf virus (RDV) & [138] \\
\hline & Pns4 & Injection & RDV replication in cultured cells & [139] \\
\hline \multirow{2}{*}{ Graminella nigrifrons } & peptidoglycan recognition protein (PGRP-LC) & Injection & high mortality & [140] \\
\hline & PGRPs & Injection & possible interaction with Rhabdovirus transmission & [141] \\
\hline Circulifer tenellus & hexamine & Injection & high mortality & [142] \\
\hline \multicolumn{5}{|l|}{ Thrips } \\
\hline \multirow{2}{*}{ Frankliniella occidentalis } & \multirow{2}{*}{ V-ATPase-B } & Injection & mortality and reduced fertility & [143] \\
\hline & & bacteria & systemic knockdown phenotypes & [144] \\
\hline \multicolumn{5}{|l|}{ Beetles } \\
\hline \multirow{6}{*}{ Diabrotica virgifera } & Lac2 and CHS2 & Injection & prevention of post-molt cuticular tanning and reduced chitin levels in midguts & [145] \\
\hline & Suf7 ortholog (Snf7) & Artificial Feeding & growth inhibition and eventual mortality & {$[31,146]$} \\
\hline & V-ATPase & Artificial Feeding & High mortality & [147] \\
\hline & cysteine protease (RS5) and immune gene (att1) & Artificial Feeding & Effect on survival & [148] \\
\hline & hunchback $(h b)$ and brahma $(b r m)$ & Artificial Feeding & embryonic development & [149] \\
\hline & chromatin remodeling ATPase & Artificial Feeding & reduction of fecundity & [150] \\
\hline
\end{tabular}


The peach potato aphid Myzus persicae is probably the most important aphid species as virus vector and transmits many important plant viruses including Potato virus Y (PVY), Potato leafroll virus (PLRV) and Cucumber mosaic virus in many regions of the world [53]. Thus far, about 17 genes showed significant effects on the insect after silencing. For example, M. persicae feeding on the transgenic plants producing the dsRNAs or siRNA of salivary proteins MpC002, MpPIntO1, and MpPIntO2; receptor of activated kinase C gene MpRack1 [46,61,151]; serine protease (MySP) [62]; Acetylcholinesterase 2 gene MpAChE2; V-ATPase E; 40S ribosomal protein S5-like isoform-1 Rps5; SWI/SNF-related matrix-associated actin-dependent regulator of chromatin subfamily $\mathrm{D}$ member 1-like gene SMARCD1; tubulin folding cofactor D gene TBCD; mediator complex subunit 31 Med31; ribosomal protein S14 Rps14 [63], hb [64], MpMIF1 [59] and Aquaporin gene MpAQP1; sucrase gene MpSUC1; and sugar transporter gene MpSt4 [65], resulted in significant reduction in the target gene expression and reduced fecundity. Aside from plant-mediated silencing, several cases in which plants expressing lectins for controlling M. persicae were reported and those include Galanthus nivalis agglutinin, GNA expressing tobacco and potato plants [66,67], Allium sativum leaf lectin, ASAL [68], Allium cepa agglutinin, ACA expressing mustard [69], Pinellia ternate agglutinin, PTA expressing tobacco plants [70,152], Dioscorea batatas tuber lectin 1, DB1 [71], legume lectins: ConA expressing potato plants [72], Jacalins: Helianthus tuberosus agglutinin, HTA expressing tobacco plants [73] and NICTABA-related lectin, AtPP2 expressing in Arabidopsis [74], all showed significant insecticidal activity against $M$. persicae.

The tobacco aphid Myzus nicotianae is another destructive pest distributed worldwide. M. nicotianaei is known to transmit potyviruses, umbraviruses and polioviruses (http://www. ictvonline.org/). Although silencing genes of this aphid species have not been reported, transgenic plants using lectins were developed against tobacco aphids and the plants showed resistance. Tobacco transgenic plants using ASAL [75], Zephyranthes grandiflora agglutinin, ZGA [76], Pinellia pedatisecta agglutinin, PPA [77] and Sambucus nigra agglutinin, SNA-I' [78] showed significant insecticidal activity against this aphid species, suggesting that using silencing plants against aphid genes has the potential for pest control using this strategy.

Aphis gossypii is a small aphid distributed worldwide and having host range of about 90 plant families and causes leaf yellowing and weakens plants [153]. A. gossypii transmits plants viruses belonging to the families Caulimoviridae and Luteoviridae. In 2014, Gong et al. [79] demonstrated the knockdown of carboxylesterase gene CarE in $A$. gossypii by oral feeding dsRNA-CarE $(100 \mathrm{ng} / \mu \mathrm{L})$ and the results showed 33\% reduction in gene expression. Suppression of CarE expression increased susceptibility to omethoate. This study indicated that CarE is a major target for organophosphate (OPs) resistance in A. gossypii. Similarly, Over-expression of Cytochrome P450 monooxygenase gene CYP6DA2 increased sensitivity to spirotetramat, alpha-cypermethrin and the toxicity of gossypol to cotton aphids $[80,81]$. Another study has demonstrated the silencing of the odorant-binding protein $2(O B P 2)$ which resulted in impaired host-seeking and oviposition behavior of $A$. gossypii [82]. Furthermore, cotton transgenic plants expressing Amaranthus caudatus agglutinin (amaranthin) conferred enhanced resistance to A. gossypii [83].

The grain aphid Sitobion avenae causes serious damage in cereal crops, especially wheat, by direct feeding and indirectly by transmitting members of plant viruses belonging to the Luteoviridae and Potyviridae [53]. Approaches combining different methods in knocking down S. avenae genes using RNAi were demonstrated and the results were remarkable. For example, silencing cytochrome $c$ oxidase subunit VIIc precursor, zinc finger protein and three unknown proteins [84] and secreted salivary peptide DSR32, salivary protein DSR33, serine protease $1 D S R 48$ [85] resulted in high mortality rates. Another study has shown silencing of $S$. avenae catalase CAT gene which significantly influenced its survival [86]. Oral delivery of olfactory receptor dsRNA [87] resulted in mortality and induced wing morph differentiation in S. avenae, while injection of dsRNA of Ace1 reduced fecundity [88]. More recently, Wang et al. (2015) [85] performed de novo transcriptome sequencing of grain aphid and out of 66 unigenes selected for dsRNA artificial diet assays, four of these genes: cytochrome 
c oxidase subunit VII c precursor, secreted salivary peptide, salivary protein MYS2 and serine protease 1 caused high mortality rates among treated aphids. Silencing of Carboxylesterase gene CbE E4 [90] and Acetylcholinesterase gene Ace1 [88] impaired their tolerance to insecticides. Similarly, Bird cherry-oat aphid Rhopalosiphum padi which transmits potyviruses was fed with Ace1 dsRNA resulting in increased susceptibility to insecticides (pirimicarb and malathion) and reduced fecundity [88]. Furthermore, transgenic plants with GNA lectin reduced nymph production by $46.9 \%$ [89].

The green bug Schizaphis graminum is a major pest of small grains and causes damage by direct feeding which induces phytotoxic responses that directly influence the crop yield [53]. S. graminum transmits Barley yellow dwarf virus (BYDV, Luteovirus) and Cereal yellow dwarf virus (CYDV, Poleovirus), the most economically important virus diseases of cereal crops worldwide [154]. As in A. pisum, silencing C002 in S. graminum caused significant lethality of the insect [91]. Similarly, transgenic plants expressing PTA also showed significant insecticidal activity against the insect [92].

Lipaphis erysimi is the mustard aphid and transmits turnip mosaic potyviruses [155]. Plants expressing dsRNA against the genes GNA, ASAL, ACA [69,93] and wheat germ agglutinin, WGA [94] showed significant insecticidal activity against this aphid species. However, among them, $A C A$-expressing mustard plants were found to be most toxic to the mustard aphids [69]. Another insect vector, Aulacorthum solani, known to transmit Soybean dwarf virus (SbDV) [156], showed decreased fecundity when exposed to GNS-transgenic plants [95].

\subsection{Whiteflies}

Whiteflies (family Aleyrodidae) are tiny $1 \mathrm{~mm}$ long sap-sucking insects that feed on hundreds of plant species and cause damage by direct feeding, and indirectly by transmitting plant viruses. A total of five whitefly spp (Bemisia tabaci, Bemisia afer, Trialeurodes vaporariorum, T. abutiloneus and T. ricini) are known to transmit plant viruses in the genera Begomovirus, Carlavirus, Crinivirus, Ipomovirus, and Torradovirus [157,158]. During the past two decades, B. tabaci (Gennadius) (Hemipetra: Aleyrodidae) has been considered one of the most economically important insect-vector complexes, threatening major crops worldwide. B. tabaci is the most important whitefly species as phloem-feeder and virus vector. This insect transmits more than 280 plant viruses that belong to the genera Begomovirus, Crinivirus, Carlavirus, Torradovirus and Ipomovirus, and known as one of the most successful insects that developed resistance to all major insecticide classes [157,158].

The application of RNAi technology has been demonstrated in whiteflies and showed promising results to be used as a new approach, pesticide-free method to control whiteflies. First report about the RNAi machinery being present in whiteflies was by Ghanim et al. (2007) [37]. In this study, the authors demonstrated that injection of dsRNA resulted in significant reduction in the expression of the targeted mRNAs in different organs of the insect. Introducing dsRNA and siRNAs of actin ortholog into the insect for ADP/ATP translocase, alpha-tubulin, ribosomal protein L9 (RPL9), and Vacuolar-type ATPase A subunit caused $29 \%-97 \%$ mortality after six days of feeding [96]. Similarly, a study showed efficient silencing of the P450 CYP6M1 gene which reduced gene expression, increased mortality and reduced the ability of the insect to detoxify imidacloprid and nicotine in both MEAM1 and MED biotypes [97].

B. tabaci feeding on transgenic tobacco plants expressing dsRNA against $v$-ATPase A [98] and the osmoregulators aquaporin, AQP and alpha glucodiase, AGLU [99], showed significant reduction in transcript levels of the target genes in the insect, and caused various levels of mortality. Recently, it was demonstrated that expressing dsRNA of whitefly in the entomapthogenic fungus Isaria fumosorosea, successfully silenced the insect Toll-like receptor 7 (TLR7) gene by infecting nymphs and increased the mortality rate [45].

Plant-mediated gene silencing also showed effects on whitefly fitness and development. Suppressing the terpenoid synthesis in tobacco plants via gene silencing improved whitefly fitness and favored vector-virus mutualism [100]. Similarly, silencing protein kinase (GhMPK3) by VIGS resulted in suppression of the MPK-WRKY-jasmonic acid (JA) and ethylene (ET) pathways and resulted in enhanced whitefly susceptibility and significant effects on eggs and pupa [101]. 


\subsection{Planthoppers}

Planthoppers are among the most important vectors that transmit plant viruses and approximately transmit 3\% of all plant viruses (Tenuivirus, Nucleorhabdovirus, Fijivirus, Phytoreovirus, and Oryzavirus) worldwide [1]. Planthoppers (Family Delphacidae) transmits viruses to the Poaceae including maize, rice, sugarcane, Sorghum and wheat.

The brown planthopper (BPH) Nilaparvata lugens is the best known plant virus vector in southeast Asia and transmits both rice grassy stunt (RGSV) and rice ragged stunt (RRSV) viruses in rice in a persistent manner [159]. An efficient and convenient RNAi technique was demonstrated by silencing $N$. lugens genes through various delivery methods including injections (calreticulin, cathepsin- $B$, beta2) [102], artificial feeding (trehalose phosphate synthase, NITPS) [41]/ingestion of V-ATPase-E, $21 E 01$ [103]. Further studies demonstrated silencing by feeding on transgenic plants expressing dsRNA of three $N$. lugens midgut expressing genes, the hexose transporter gene HT1, the carboxypeptidase gene $(C A R)$ and the trypsin-like serine protease gene (TRY). The expression of the three genes was reduced, however, in the midguts, no phenotypic effects were observed [47]. Knockdown of N. lugens NlFoxA significantly decreased the number of offspring and had significant impact on the development of $N$. lugens ovaries [104]. Silencing the ecdysone receptor in three planthopper virus vectors: N. lugens, Laodelphgax striatellus, vectors for Rice stripe virus (RSV) and Sogatella furcifera, the vector of Southern rice black-streaked dwarf virus (SRBSDV), resulted in phenotypic defects in molting nymph mortality [105]. Silencing of coronatine insensitive1 (COI1) in rice plants increased their defense response and increased $N$. lugens susceptibility to feeding on these plants [106]. Silencing chitin synthases (CHS1 and CHS1a) resulted in elongated distal wing pads and crimpled cuticle phenotypes and eventually led to insect lethality; whereas the phenotypes caused by injection of CHSb showed increased mortality [107]. Xue et al. (2013) [108] demonstrated that silencing genes associated with flight: indirect flight muscle (IFM) and dorsal longitudinal muscle (DLM) in BPH affected flight. Xu et al. (2013) [109] comprehensively investigated the repertoire of core genes involved in siRNA and miRNA pathways in the BPH and the results demonstrated that the miRNA pathway was involved in BPH metamorphosis as depletion of the Argonaute (AGO1) or Dicer (Dcr-1) genes severely impaired ecdysis. RNAi experiments using the $N$. lugens Dcr-2 gene showed $55 \%$ decrease of the gene expression after four days of feeding and no developmental changes were observed in the insect [110].

RNAi knockdown of glutamine synthase (GS) gene reduced fecundity of N. lugens by $64.6 \%$, disrupted ovary development and inhibited vitellogenin $(V g)$ expression [111]. Zhang et al. (2013) [112] demonstrated that Dcr-1 was crucial for the regulation of oogenesis in telotrophic ovary in N. lugens. Similarly, silencing of Hsp70 and Arginine kinase (Argk) are essential for survival and triazophos increased thermotolerance in BPH [113]. RNAi targeting two N. lugens GST genes, GSTe1 and GSTm2, significantly increased the sensitivity of the fourth instar nymphs to chlorpyrifos [114]. N. lugens feeding on transgenic rice plants expressing ecdysone receptor $(E c R)$ dsRNA significantly reduced the survival rate of the offspring [115]. Lu et al. (2015) [116] also suggested that using RNAi against Vg receptor is crucial for $\mathrm{Vg}$ uptake into oocytes that influence insect fecundity.

Silencing the enolase gene (Eno1) from N. lugens showed significant down-regulation of the mRNA levels along with decreased egg lay and population size in the next generation [117]. In the same insect, RNAi of Bicaudal-C suggested its role in oogenesis and oocyte maturation [118]. In another study, silencing acyl-coenzyme A oxidase (ACO) [119,120] and glutamine synthetase (GS) [121] decreased the reproduction and population growth in BPH females, while knockdown of NIHsp90 by dsRNA injection reduced the survival and verified its role in thermotolerance [122]. Another study demonstrated the importance of $\beta$-N-acetylhexosaminidase gene family in BPH and the silencing of this gene caused molting failure and death [123]. Yang et al. (2016) [124] demonstrated that knockdown of two trehalose-6-phosphate synthases (TPS1 and TPS2) severely affected chitin metabolism and increased molting deformities and mortality rates, and showed that the nutritional signaling regulates Vitelogenin synthesis and egg development in N. lugens [125,126]. Finally, using gene silencing, Bao et al. 
(2016) [127] demonstrated the role of P450 proteins (CYP6AY1 and CYP6ER1) in imidacloprid resistance and suggested that CYP6ER1 gene could be induced by imidacloprid.

High mortality rates in L. striatellus, a small planthopper that feeds and damages rice by sap-sucking and transmitting plant viruses, were obtained when chitinase was silenced [128], while knocking down the Halloween gene Shade $(S h D)$ decreased the expression of $E c R$ gene and caused nymphal lethality and delayed development [160]. Knockdown of the Halloween gene disembodied (dib) in this insect delayed nymphal growth and caused mortality [129], while gene silencing by dsRNA feeding showed that the cytochrome P450 monooxygenase CYP353D1v2 could significantly enhance the sensitivity of L. striatellus to imidacloprid [130].

Silencing wingless in the white-backed planthopper S. furcifera, which feeds on rice and especially attacks the seedling stage and transmits several plant viruses, resulted in significantly shorter and deformed wings [133]. Knockdown of the disembodied (dib) gene in this insect delayed nymphal growth and caused high mortality rates [129]. Introduction of dsRNA of the Halloween gene phantom (phd) in the diet of second instars successfully knocked down the expression levels of ecdysteroid hormones ecdysone (E) and 20-hydroxyecdysone (20E), and caused mortality, while slowing down ecdysis during the nymphal stages [161]. In another study, dietary ingestion of ryanodine receptors (RyR1 and RyR2) dsRNA significantly reduced the mRNA level of RyR in the treated nymphs by $77.9 \%$ and $81.8 \%$ respectively, and greatly decreased chlorantraniliprole-induced mortality [134]. Dietary introduction of dsRNA of the Halloween gene spook (spo) to the second instars successfully reduced the target gene and reduced expression level of Ecr, caused mortality and delayed development during nymphal stages of S. furcifera [135].

\subsection{Leafhoppers}

Leafhoppers are plant feeders, known to transmit plant viruses and phytoplasma in many important crops. They belong to the family Cicadellidae and Delphacidae and transmit semi-persistent, persistent, and propagative viruses. Those viruses belong to several families that include Bunyaviridae, Geminiviridae, Reoviridae and Rhabdoviridae [1].

The green rice leafhopper Nephotettix, is an important rice pest in Asia and an efficient vector of the virus that cause the tungro disease. Recently, RNAi has been successfully demonstrated in Nephotettix cincticeps. Silencing was achieved by injecting dsRNA of laccase-2 into first instar nymphs, which resulted in high mortality rates and depigmentation of the side lines on the body [137]. Silencing was also demonstrated in the black-faced leafhopper Graminella nigrifrons, known to be the only vector of the persistent propagative Maize fine streak virus (MFSV). Knockdown of peptidoglycan recognition protein (PGRP-LC) in this insect resulted in significant mortality that reached more than $90 \%$ [140]. In the beet leafhopper, Circulifer tenellus known to transmit cutoviruses that cause diseases in sugar beet, beans and other important crops, successful silencing was demonstrated by reducing the expression of hexamine, resulting in significant reduction in phenoloxidase-like activity and increased mortality [142].

\subsection{Thrips}

Thrips (Thysanoptera) are minute insects and are highly polyphagous and transmit plant viruses that belong to the genera Carmovirus, Ilarvirus, Sobemovirus and Tospovirus [1]. Frankliniella occidentalis is the most important thrips species distributed worldwide and vectors Tomato spotted wilt virus (TSWV). Silencing V-ATPase-B gene of $F$. occidentalis decreased the abundance of V-ATPase-B protein and resulted in female mortality and reduced fertility [143]. When ingested, dsRNA-expressing bacterial strains, successfully competed with the wild-type microflora, and sustainably mediated systemic knockdown phenotypes that were horizontally transmitted [144].

\subsection{Beetles}

Beetles (Coleoptera) include several families: Chrysomelidae, Coccinellidae, and Meloidae. Besides being tissue feeders, beetles also transmit viruses belonging to genera Bromovirus, Carmovirus, 
Comovirus, Machlomovirus, Sobemovirus, and Tymovirus [1]. The Western corn rootworm (WCR) (Diabrotica virgifera virgifera) (family Chrysomelidae) is one of the most devastating corn rootworm species in North America which transmits Maize chlorotic mottle virus (MCMV) [162]. One of the recent approaches to manage WCR involves using gene silencing. dsRNA was injected against the Lac2 and CHS2 genes and resulted in the prevention of post-molt cuticular tanning and reduced chitin levels in the midgut [145]. Bolognesi et al. (2012) and Ramaseshadri et al. (2013) [31,146] successfully suppressed Snf7 ortholog (Snf7) transcripts by injection of corresponding dsRNA in WCR, resulting in growth inhibition and mortality. Rangasamy and Siegfried (2012) [147] demonstrated effective silencing in WCR after feeding adults with artificial diet supplemented with dsRNA for V-ATPase. This feeding caused up to $95 \%$ mortality within two weeks of exposure compared to the control. The same method showed effective silencing of two genes: cysteine protease (RS5) and immunue gene (att1) [148]. Knockdown of two WCR genes, hunchback ( $h b)$ and brahma (brm), caused significant decrease in the transcripts of both genes in adult females and complete arrest of egg hatching was obtained, suggesting that both genes have functions in WCR embryonic development [149]. More recently, Fishilevich et al. (2016) [150] demonstrated that silencing of the chromatin remodeling gene ATPase resulted in decreasing fecundity.

\section{RNAi in Plant Virus-Insect Interactions}

Very few studies were conducted to investigate the prevention of virus transmission by vectors. One representative example was conducted in leafhoppers, in which the knockdown of the non-structural viral protein Pns10 gene strongly inhibited the formation of tubules which in turn prevented the intercellular spread and transmission of Rice dwarf virus (RDV) by N. cincticeps [138]. Similarly, Chen et al. (2015) [139] demonstrated knockdown of Pns4 in N. cincticeps which resulted in increased replication of RDV in cultured cells of $N$. cincticeps. This result demonstrated the major role of this protein in viroplasm formation for viral replication and assembly of progeny virions during infection in N. cincticeps. In G. nigrifrons, the down-regulation of PGRPs in MFSV, suggested its possible interaction with rhabdovirus transmission [141].

In planthoppers, silencing of the viral gene P7-1 was demonstrated by using in vitro synthesized dsRNA. This treatment resulted in the disassembly of tubule and to the prevention of virus spread in the insect [136]. Another study showed that silencing Agronaute 2 in L. striatellus affected Himetobi $\mathrm{P}$ virus (HiPV) [131]. Another study has demonstrated that silencing the planthopper Laodelphax striatellus cuticular protein (CPR1) resulted in reduced ability to transmit Rice stripe virus (RSV) by the vector [132]. In thrips, it was shown by silencing that the nonstructural (NSs) protein of TSWV aids in the replication of baculoviruses in lepidopteran cell lines [163]. This result hints on the role of this protein during TSWV transmission by thrips.

In B. tabaci, several studies have demonstrated the importance of insect proteins in the transmission of begomoviruses. Such examples include the small heat shock protein (BtHSP16) that was shown to interact with Tomato yellow leaf curl Sardinia virus (TYLCSV) coat protein (CP) [164], and heat shock protein 70 (HSP70) that interacts with Tomato yellow leaf curl virus (TYLCV) CP [165]. Recently, de Paula et al. (2015) [166] reported that the virus titer was reduced in whiteflies that were fed on plants expressing siRNA of the viral replication associated protein gene of Bean golden mosaic virus (BGMV).

\section{Conclusions and Future Perspectives}

In this review, we summarized known cases in which successful gene silencing in insect vectors for plant pathogens were reported. Silencing in non-model insects was in most cases designed for causing general effects such as mortality and population size control as a way for pest control. Very few cases investigated silencing genes that have direct role in virus transmission. The various delivery methods used for introducing silencing RNA molecules into the insect were successful in inducing silencing. While artificial feeding or injection are best methods for research purposes, expression of 
siRNA molecules in plant hosts for insect feeding and inducing silencing will be the best approach for developing means of RNAi-based pest control. Engineering plants for silencing will be effective in controlling persistent viruses, by silencing genes that have roles in the transmission process, or controlling the vector itself which can lead to the control of not only persistent viruses, but also non-persistent and semi-persistent ones. The design of transgenic plants for inducing silencing in insect vector will be ideal by using specific genes expressed in these groups of insects, and genes that are common to more than one insect pest.

Acknowledgments: Research in the Ghanim lab is supported by grants from the Israel Science Foundation (ISF), Binational Agricultural Research and Development Fund (BARD) and the Chief Scientist of the Ministry of Agriculture in Israel.

Author Contributions: Surapathrudu Kanakala and Murad Ghanim both wrote and approved the manuscript.

Conflicts of Interest: The authors declare no conflict of interest.

\section{References}

1. Hogenhout, S.; Ammar, E.D.; Whitfield, A.E.; Redinbaugh, M.G. Insect vector interactions with persistently transmitted viruses. Annu. Rev. Phytopathol. 2008, 46, 327-359. [CrossRef] [PubMed]

2. Fire, A.; Xu, S.; Montgomery, M.K.; Kostas, S.A.; Driver, S.E.; Mello, C.C. Potent and specific genetic interference by double-stranded RNA in Caenorhabditis elegans. Nature 1998, 391, 806-811. [CrossRef] [PubMed]

3. Hamilton, A.J.; Baulcombe, D.C. A species of small antisense RNA in posttranscriptional gene silencing in plants. Science 1999, 286, 950-952. [CrossRef] [PubMed]

4. Hammond, S.M.; Bernstein, E.; Beach, D.; Hannon, G.J. An RNA-directed nuclease mediates post-transcriptional gene silencing in Drosophila cells. Nature 2000, 404, 293-296. [PubMed]

5. Price, D.R.G.; Gatehouse, J.A. RNAi-mediated crop protection against insects. Trends Biotechnol. 2008, 26, 393-400. [CrossRef] [PubMed]

6. Belles, X. Beyond Drosophila: RNAi in vivo and functional genomics in insects. Annu. Rev. Entomol. 2010, 55, 111-128. [CrossRef] [PubMed]

7. Ding, S.W. RNA-based antiviral immunity. Nat. Rev. Immunol. 2010, 10, 632-644. [CrossRef] [PubMed]

8. Bernstein, E.; Caudy, A.A.; Hammond, S.M.; Hannon, G.J. Role for a bidentate ribonuclease in the initiation step of RNA interference. Nature 2001, 409, 363-366. [CrossRef] [PubMed]

9. Elbashir, S.M.; Lendeckel, W.; Tuschl, T. RNA interference is mediated by 21- and 22-nucleotide RNAs. Gene Dev. 2001, 15, 188-200. [CrossRef] [PubMed]

10. Bass, B.L. Double-stranded RNA minireview as a template for gene silencing. Cell 2000, 101, 235-238. [CrossRef]

11. Simmer, F.; Tijsterman, M.; Parrish, S.; Koushika, S.P.; Nonet, M.L.; Fire, A.; Ahringer, J.; Plasterk, R.H.A. Loss of the putative RNA-directed RNA polymerase RRF-3 makes C. elegans hypersensitive to RNAi. Curr. Biol. 2002, 12, 1317-1319. [CrossRef]

12. Hammond, S.M. Dicing and slicing-the core machinery of the RNA interference pathway. FEBS Lett. 2005, 579, 5822-5829. [CrossRef] [PubMed]

13. Eaton, B.A.; Fetter, R.D.; Davis, G.W. Dynactin is necessary for synapse stabilization. Neuron 2002, 34, 729-741. [CrossRef]

14. Baum, J.A.; Bogaert, T.; Clinton, W.; Heck, G.R.; Feldmann, P.; Ilagan, O.; Johnson, S.; Plaetinck, G.; Munyikwa, T.; Pleau, M.; et al. Control of coleopteran insect pests through RNA interference. Nat. Biotechnol. 2007, 25, 1322-1326. [CrossRef] [PubMed]

15. Mao, Y.B.; Cai, W.J.; Wang, J.W.; Hong, G.J.; Tao, X.Y.; Wang, L.J.; Huang, Y.P.; Chen, X.Y. Silencing a cotton bollworm P450 monooxygenase gene by plant-mediated RNAi impairs larval tolerance of gossypol. Nat. Biotechnol. 2007, 25, 1307-1313. [CrossRef] [PubMed]

16. Chen, X.; Tian, H.; Zou, L.; Tang, B.; Hu, J.; Zhang, W. Disruption of Spodoptera exigua larval development by silencing chitin synthase gene A with RNA interference. Bull. Entomol. Res. 2008, 98, 613-619. [CrossRef] [PubMed] 
17. Tian, H.; Peng, H.; Yao, Q.; Chen, H.; Xie, Q.; Tang, B.; Zhang, W. Developmental control of a Lepidopteran pest Spodoptera exigua by ingestion of bacterial expressing dsRNA of a non-midgut gene. PLoS ONE 2009, 4, e6225. [CrossRef] [PubMed]

18. Siomi, H.; Siomi, M.C. On the road to reading the RNA-interference code. Nature 2009, 457, $396-404$. [CrossRef] [PubMed]

19. Saleh, M.C.; van Rij, R.P.; Hekele, A.; Gillis, A.; Foley, E.; O'Farrell, P.H.; Andino, R. The endocytic pathway mediates cell entry of dsRNA to induce RNAi silencing. Nat. Cell Biol. 2006, 8, 793-802. [CrossRef] [PubMed]

20. Ulvila, J.; Parikka, M.; Kleino, A.; Sormunen, R.; Ezekowitz, R.A.; Kocks, C.; Rämet, M. Double-stranded RNA is internalized by scavenger receptor-mediated endocytosis in Drosophila S2 cells. J. Biol. Chem. 2006, 281, 14370-14375. [CrossRef] [PubMed]

21. Jose, A.M.; Hunter, C.P. Transport of sequence-specific RNA interference information between cells. Annu. Rev. Genet. 2007, 41, 305-330. [CrossRef] [PubMed]

22. Whangbo, J.S.; Hunter, C.P. Environmental RNA interference. Trends Genet. 2008, 24, 297-305. [CrossRef] [PubMed]

23. Feinberg, E.H.; Hunter, C.P. Transport of dsRNA into cells by the transmembrane protein SID-1. Science 2003, 301, 1545-1547. [CrossRef] [PubMed]

24. McEwan, D.L.; Weisman, A.S.; Hunter, C.P. Uptake of extracellular double-stranded RNA by SID-2. Mol. Cell 2012, 47, 746-754. [CrossRef] [PubMed]

25. Miller, S.C.; Miyata, K.; Brown, S.J.; Tomoyasu, Y. Dissecting systemic RNA interference in the red flour beetle Tribolium castaneum: Parameters affecting the efficiency of RNAi. PLoS ONE 2012, 7, e47431. [CrossRef] [PubMed]

26. Pridgeon, J.W.; Zhao, L.; Becnel, J.J.; Strickman, D.A.; Clark, G.G.; Linthicum, K.J. Topically applied AaeIAP1 double-stranded RNA kills female adults of Aedes aegypti. J. Med. Entomol. 2008, 45, 414-420. [CrossRef]

27. Huvenne, H.; Smagghe, G. Mechanism of dsRNA uptake in insects and potential of RNAi in pest control: A review. J. Insect Physiol. 2010, 56, 227-235. [CrossRef] [PubMed]

28. Terenius, O.; Papanicolaou, A.; Garbutt, J.S.; Eleftherianos, I.; Huvenne, H.; Kanginakudru, S.; Albrechtsen, M.; An, C.; Aymeric, J.L.; Barthel, A.; et al. RNA interference in Lepidoptera: An overview of successful and unsuccessful studies and implications for experimental design. J. Insect Physiol. 2011, 57, 231-245. [CrossRef] [PubMed]

29. Mao, J.; Zeng, F. Feeding-based RNA interference of a gap gene is lethal to the pea aphid, Acyrthosiphon pisum. PLoS ONE 2012, 7, e48718. [CrossRef] [PubMed]

30. Loy, D.L.; Mogler, M.A.; Loy, D.S.; Janke, B.; Kamrud, K.; Scura, E.D.; Harris, D.L.H.; Bartholomay, L.C. Double-stranded RNA provides sequence dependent protection against infectious myonecrosis virus in Litopenaeus vannamei. J. Gen. Virol. 2012, 93, 880-888. [CrossRef] [PubMed]

31. Bolognesi, R.; Ramaseshadri, P.; Anderson, J.; Bachman, P.; Clinton, W.; Flannagan, R.; Ilagan, O.; Lawrence, C.; Levine, S.; Moar, W.; et al. Characterizing the mechanism of action of double-stranded RNA activity against western corn rootworm (Diabrotica virgifera virgifera LeConte). PLoS ONE 2012, 7, e47534. [CrossRef] [PubMed]

32. Kumar, P.; Pandit, S.S.; Baldwin, I.T. Tobacco rattle virus vector: A rapid and transient means of silencing Manduca sexta genes by plant mediated RNA interference. PLoS ONE 2012, 7, e31347. [CrossRef] [PubMed]

33. Scott, J.G.; Michel, K.; Bartholomay, L.C.; Siegfried, B.D.; Hunter, W.B.; Smagghe, G.; Zhu, K.Y.; Douglas, A.E. Towards the elements of successful insect RNAi. J. Insect Physiol. 2013, 59, 1212-1221. [CrossRef] [PubMed]

34. Kennerdell, J.R.; Carthew, R.W. Use of dsRNA mediated genetic interference to demonstrate that frizzled and frizzled 2 act in the wingless pathway. Cell 1998, 95, 1017-1026. [CrossRef]

35. Mutti, N.S.; Park, Y.; Reese, J.C.; Reeck, G.R. RNAi knockdown of a salivary transcript leading to lethality in the pea aphid, Acyrthosiphon pisum. J. Insect Sci. 2006, 6. [CrossRef] [PubMed]

36. Jaubert-Possamai, S.; le Trionnaire, G.; Bonhomme, J.; Christophides, G.K.; Rispe, C.; Tagu, D. Gene knockdown by RNAi in the pea aphid Acyrthosiphon pisum. BMC Biotechnol. 2007, 7. [CrossRef] [PubMed]

37. Ghanim, M.; Kontsedalov, S.; Czosnek, H. Tissue-specific gene silencing by RNA interference in the whitefly Bemisia tabaci (Gennadius). Insect Biochem. Mol. Biol. 2007, 37, 732-738. [CrossRef] [PubMed]

38. Whyard, S.; Singh, A.D.; Wong, S. Ingested double-stranded RNAs can act as species-specific insecticides. Insect Biochem. Mol. Biol. 2009, 39, 824-832. [CrossRef] [PubMed] 
39. Araujo, R.N.; Santos, A.; Pinto, F.S.; Gontijo, N.F.; Lehane, M.J.; Pereira, M.H. RNA interference of the salivary gland nitrophorin 2 in the triatomine bug Rhodnius prolixus (Hemiptera: Reduviidae) by dsRNA ingestion or injection. Insect Biochem. Mol. Biol. 2006, 36, 683-693. [CrossRef] [PubMed]

40. Shakesby, A.; Wallace, I.S.; Isaacs, H.V.; Pritchard, J.; Roberts, D.M.; Douglas, A.E. Water-specific aquaporin involved in aphid osmoregulation. Insect Biochem. Mol. Biol. 2009, 39, 1-10. [CrossRef] [PubMed]

41. Chen, J.; Zhang, D.; Yao, Q.; Zhang, J.; Dong, X.; Tian, H.; Zhang, W. Feeding-based RNA interference of a trehalose phosphate synthase gene in the brown planthopper, Nilaparvata lugens. Insect Mol. Biol. 2010, 19, 777-786. [CrossRef] [PubMed]

42. Li, X.; Zhang, M.; Zhang, H. RNA interference of four genes in adult Bactrocera dorsalis by feeding their dsRNAs. PLOS ONE 2011, 6, e17788. [CrossRef] [PubMed]

43. Wang, Y.; Zhang, H.; Li, H.; Miao, X. Second-generation sequencing supply an effective way to screen RNAi targets in large scale for potential application in pest insect control. PLoS ONE 2011, 6, e18644. [CrossRef] [PubMed]

44. Zhang, X.; Zhang, J.; Zhu, K. Chitosan/double-stranded RNA nanoparticle-mediated RNA interference to silence chitin synthase genes through larval feeding in the African malaria mosquito (Anopheles gambiae). Insect Mol. Biol. 2010, 19, 683-693. [CrossRef] [PubMed]

45. Chen, X.; Li, L.; Hu, Q.; Zhang, B.; Wu, W.; Jin, F.; Jiang, J. Expression of dsRNA in recombinant Isaria fumosorosea strain targets theTLR7 gene in Bemisia tabaci. BMC Biotechnol. 2015, 15. [CrossRef] [PubMed]

46. Pitino, M.; Coleman, A.D.; Maffei, M.E.; Ridout, C.J.; Hogenhout, S.A. Silencing of aphid genes by dsRNA feeding from plants. PLoS ONE 2011, 6, e25709. [CrossRef] [PubMed]

47. Zha, W.; Peng, X.; Chen, R.; Du, B.; Zhu, L.; He, G. Knockdown of midgut genes by dsRNA-transgenic plant-mediated RNA interference in the hemipteran insect Nilaparvata lugens. PLoS ONE 2011, 6, e20504. [CrossRef] [PubMed]

48. Jouanin, L.; Bonadé-Bottino, M.; Girard, C.; Morrot, G.; Giband, M. Transgenic plants for insect resistance. Plant Sci. 1998, 131, 1-11. [CrossRef]

49. Chattopadhyay, A.; Bhatnagar, N.B.; Bhatnagar, R. Bacterial insecticidal toxins. Crit. Rev. Microbiol. 2004, 30, 33-54. [CrossRef] [PubMed]

50. Hajeri, S.; Killiny, N.; El-Mohtar, C.; Dawson, W.O.; Gowda, S. Citrus tristeza virus-based RNAi in citrus plants induces gene silencing in Diaphorina citri, a phloem-sap sucking insect vector of citrus greening disease (Huanglongbing). J. Biotechnol. 2014, 176, 42-49. [CrossRef] [PubMed]

51. Yoo, B.C.; Kragler, F.; Varkonyi-Gasic, E.; Haywood, V.; Archer-Evans, S.; Lee, Y.M.; Lough, T.J.; Lucas, W.J. A systemic small RNA signaling system in plants. Plant Cell 2004, 16, 1979-2000. [CrossRef] [PubMed]

52. Fereres, A.; Raccah, B. Plant virus transmission by insects. eLS 2015. [CrossRef]

53. Blackman, R.L.; Eastop, V.F. Aphids on the World's Crops: An Identification and Information Guide; Wiley, John \& Sons: Chichester, UK, 2000; p. 476.

54. Bos, J.I.; Prince, D.; Pitino, M.; Maffei, M.E.; Win, J.; Hogenhout, S.A. A functional genomics approach identifies candidate effectors from the aphid species Myzus persicae (green peach aphid). PLoS Genet. 2010, 6, e1001216. [CrossRef] [PubMed]

55. Sapountzis, P.; Duport, G.; Balmand, S.; Gaget, K.; Jaubert-Possamai, S.; Febvay, G.; Charles, H.; Rahbé, Y.; Colella, S.; Calevro, F. New insight into the RNA interference response against cathepsin-L gene in the pea aphid, Acyrthosiphon pisum: Molting or gut phenotypes specifically induced by injection or feeding treatments. Insect Mol. Biol. 2014, 51, 20-32. [CrossRef] [PubMed]

56. Wang, W.; Luo, L.; Lu, H.; Chen, S.; Kang, L.; Cui, F. Angiotensin-converting enzymes modulate aphid-plant interactions. Sci. Rep. 2015, 5. [CrossRef] [PubMed]

57. Will, T.; Vilcinskas, A. The structural sheath protein of aphids is required for phloem feeding. Insect Biochem. Mol. Biol. 2015, 57, 34-40. [CrossRef] [PubMed]

58. Zhang, Y.; Lu, Z. Peroxiredoxin 1 protects the pea aphid Acyrthosiphon pisum from oxidative stress induced by Micrococcus luteus infection. J. Invertebr. Pathol. 2015, 127, 115-121. [CrossRef] [PubMed]

59. Naessens, E.; Dubreuil, G.; Giordanengo, P.; Baron, O.L.; Minet-Kebdani, N.; Keller, H.; Coustau, C. A secreted MIF cytokine enables aphid feeding and represses plant immune responses. Curr. Biol. 2015, 25, 1898-1903. [CrossRef] [PubMed] 
60. Rausch, M.A.; Chougule, N.P.; Deist, B.R.; Bonning, B.C. Modification of Cry4Aa toward improved toxin processing in the gut of the pea aphid, Acyrthosiphon pisum. PLoS ONE 2016, 11, e0155466. [CrossRef] [PubMed]

61. Pitino, M.; Hogenhout, S.A. Aphid protein effectors promote aphid colonization in a plant species-specific manner. Mol. Plant Microbe Interact. 2013, 26, 130-139. [CrossRef] [PubMed]

62. Bhatia, V.; Bhattacharya, R.; Uniyal, P.L.; Singh, R.; Niranjan, R.S. Host generated siRNAs attenuate expression of serine protease gene in Myzus persicae. PLoS ONE 2012, 7, e46343. [CrossRef] [PubMed]

63. Guo, H.; Song, X.; Wang, G.; Yang, K.; Wang, Y.; Niu, L.; Chen, X.; Fang, R. Plant-generated artificial small RNAs mediated aphid resistance. PLoS ONE 2014, 9, e97410. [CrossRef] [PubMed]

64. Mao, J.; Zeng, F. Plant-mediated RNAi of a gap gene-enhanced tobacco tolerance against the Myzus persicae. Transgen. Res. 2014, 23, 145-152. [CrossRef] [PubMed]

65. Tzin, V.; Yang, X.; Jing, X.; Zhang, K.; Jander, G.; Douglas, A.E. RNA interference against gut osmoregulatory genes in phloem-feeding insects. J. Insect Physiol. 2015, 79, 105-112. [CrossRef] [PubMed]

66. Hilder, V.A.; Powell, K.S.; Gatehouse, A.M.R.; Gatehouse, J.A.; Gatehouse, L.N.; Shi, Y.; Hamilton, W.D.O.; Merryweather, A.; Newell, C.A.; Timans, J.C.; et al. Expression of snowdrop lectin in transgenic tobacco plants results in added protection against aphids. Transgen. Res. 1995, 4, 18-25. [CrossRef]

67. Gatehouse, A.M.; Down, R.E.; Powell, K.S.; Sauvion, N.; Rahbé, Y.; Newell, C.A.; Merryweather, A.; Hamilton, W.; Gatehouse, J.A. Transgenic potato plants with enhanced resistance to the peach-potato aphid Myzus persicae. Entomol. Exp. Appl. 1996, 79, 295-307. [CrossRef]

68. Dutta, I.; Saha, P.; Majumder, P.; Sarkar, A.; Chakraborti, D.; Banerjee, S.; Das, S. The efficacy of a novel insecticidal protein, Allium sativum leaf lectin (ASAL), against homopteran insects monitored in transgenic tobacco. Plant Biotechnol. J. 2005, 3, 601-611. [CrossRef] [PubMed]

69. Hossain, M.A.; Maiti, M.K.; Basu, A.; Sen, S.; Ghosh, A.K.; Sen, S.K. Transgenic expression of onion leaf lectin gene in Indian mustard offers protection against aphid colonization. Crop Sci. 2006, 46, 2022-2032. [CrossRef]

70. Yao, J.; Pang, Y.; Qi, H.; Wan, B.; Zhao, X.; Kong, W.; Sun, X.; Tang, K. Transgenic tobacco expressing Pinellia ternata agglutinin confers enhanced resistance to aphids. Transgen. Res. 2003, 12, 715-722. [CrossRef]

71. Kato, T.; Hori, M.; Ogawa, T.; Muramoto, K.; Toriyama, K. Expression of gene for Dioscorea batatas tuber lectin 1 in transgenic tobacco confers resistance to green-peach aphid. Plant Biotechnol. 2010, 27, 141-145. [CrossRef]

72. Gatehouse, A.M.; Davison, G.M.; Stewart, J.N.; Gatehouse, L.N.; Kumar, A.; Geoghegan, I.E.; Birch, A.N.E.; Gatehouse, J.A. Concanavalin A inhibits development of tomato moth (Lacanobia oleracea) and peach-potato aphid (Myzus persicae) when expressed in transgenic potato plants. Mol. Breed. 1999, 5, 153-165. [CrossRef]

73. Chang, T.; Chen, L.; Chen, S.; Cai, H.; Liu, X.; Xiao, G.; Zhu, Z. Transformation of tobacco with genes encoding Helianthus tuberosus agglutinin (HTA) confers resistance to peach-potato aphid (Myzus persicae). Transgen. Res. 2003, 12, 607-614. [CrossRef]

74. Zhang, C.; Shi, H.; Chen, L.; Wang, X.; Lü, B.; Zhang, S.; Liang, Y.; Liu, R.; Qian, J.; Sun, W.; et al. Harpin-induced expression and transgenic overexpression of the phloem protein gene AtPP2-A1 in Arabidopsis repress phloem feeding of the green peach aphid Myzus persicae. BMC Plant Biol. 2011, 11. [CrossRef] [PubMed]

75. Sadeghi, A.; Smagghe, G.; Broeders, S.; Hernalsteens, J.P.; de Greve, H.; Peumans, W.J.; van Damme, E.J. Ectopically expressed leaf and bulb lectins from garlic (Allium sativum L.) protect transgenic tobacco plants against cotton leafworm (Spodoptera littoralis). Transgen. Res. 2008, 17, 9-18. [CrossRef] [PubMed]

76. Ye, S.H.; Chen, S.; Zhang, F.; Wang, W.; Tian, Q.; Liu, J.Z.; Chen, F.; Bao, J.K. Transgenic tobacco expressing Zephyranthes grandiflora agglutinin confers enhanced resistance to aphids. Appl. Biochem. Biotechnol. 2009, 158, 615-630. [CrossRef] [PubMed]

77. Wu, Z.M.; Yan, H.B.; Pan, W.L.; Jiang, B.; Liu, J.G.; Geng, B.J.; Sun, Y.T.; Wang, Y.H.; Dong, W.Q. Transform of an ectopically expressed bulb lectin gene from Pinellia pedatisecta into tobacco plants conferring resistance to aphids (Myzus nicotianae). Aust. J. Crop Sci. 2012, 6, 904.

78. Shahidi-Noghabi, S.; van Damme, E.J.; Smagghe, G. Expression of Sambucus nigra agglutinin (SNA-I') from elderberry bark in transgenic tobacco plants results in enhanced resistance to different insect species. Transgen. Res. 2009, 18, 249-259. [CrossRef] [PubMed] 
79. Gong, Y.H.; Yu, X.R.; Shang, Q.L.; Shi, X.Y.; Gao, X.W. Oral delivery mediated RNA interference of a carboxylesterase gene results in reduced resistance to organophosphorus insecticides in the cotton aphid, Aphis gossypii Glover. PLoS ONE 2014, 9, e102823. [CrossRef] [PubMed]

80. Peng, T.; Pan, Y.; Yang, C.; Gao, X.; Xi, J.; Wu, Y.; Huang, X.; Zhu, E.; Xin, X.; Zhan, C.; et al. Over-expression of CYP6A2 is associated with spirotetramat resistance and cross-resistance in the resistant strain of Aphis gossypii Glover. Pestic. Biochem. Physiol. 2016, 126, 64-69. [CrossRef] [PubMed]

81. Peng, T.; Pan, Y.; Gao, X.; Xi, J.; Zhang, L.; Yang, C.; Bi, R.; Yang, S.; Xin, X.; Shang, Q. Cytochrome P450 CYP6DA2 regulated by cap ' $n$ ' collar isoform $C(C n c C)$ is associated with gossypol tolerance in Aphis gossypii Glover. Insect Mol. Biol. 2016. [CrossRef] [PubMed]

82. Rebijith, K.; Asokan, R.; Hande, H.R.; Kumar, N.K.; Krishna, V.; Vinutha, J.; Bakthavatsalam, N. RNA interference of odorant-binding protein 2 (OBP2) of the cotton aphid, Aphis gossypii (Glover), resulted in altered electrophysiological responses. Appl. Biochem. Biotechnol. 2016, 178, 251-266. [CrossRef] [PubMed]

83. Wu, J.; Luo, X.L.; Guo, H.N.; Xiao, J.; Tian, Y. Transgenic cotton, expressing Amaranthus caudatus agglutinin, confers enhanced resistance to aphids. Plant Breed. 2006, 125, 390-394. [CrossRef]

84. Zhang, M.; Zhou, Y.; Wang, H.; Jones, H.D.; Gao, Q.; Wang, D.; Ma, Y.; Xia, L. Identifying potential RNAi targets in grain aphid (Sitobion avenae F.) based on transcriptome profiling of its alimentary canal after feeding on wheat plants. BMC Genom. 2013, 14. [CrossRef] [PubMed]

85. Wang, D.; Liu, Q.; Li, X.; Sun, Y.; Wang, H.; Xia, L. Double-stranded RNA in the biological control of grain aphid (Sitobion avenae F.). Funct. Integr. Genom. 2015, 15, 211-223. [CrossRef] [PubMed]

86. Deng, F.; Zhao, Z. Influence of catalase gene silencing on the survivability of Sitobion avenae. Arch. Insect Biochem. Physiol. 2014, 86, 46-57. [PubMed]

87. Fan, J.; Zhang, Y.; Francis, F.; Cheng, D.F.; Sun, J.R.; Chen, J.L. Orco mediates olfactory behaviors and winged morph differentiation induced by alarm pheromone in the grain aphid, Sitobion avenae. Insect Biochem. Mol. Biol. 2015, 64, 16-24. [CrossRef] [PubMed]

88. Xiao, D.; Lu, Y.H.; Shang, Q.L.; Song, D.L.; Gao, X.W. Gene silencing of two acetylcholinesterases reveals their cholinergic and non-cholinergic functions in Rhopalosiphum padi and Sitobion avenae. Pest Manag. Sci. 2015, 71, 523-530. [CrossRef] [PubMed]

89. Wang, Z.; Zhang, K.; Sun, X.; Tang, K.; Zhang, J. Enhancement of resistance to aphids by introducing the snowdrop lectin genegna into maize plants. J. Biosci. 2005, 30, 627-638. [CrossRef] [PubMed]

90. Xu, L.J.; Duan, X.L.; Lv, Y.H.; Zhang, X.H.; Nie, Z.S.; Xie, C.; Ni, Z.; Liang, R. Silencing of an aphid carboxylesterase gene by use of plant-mediated RNAi impairs Sitobion avenae tolerance of Phoxim insecticides. Transgen. Res. 2014, 23, 389-396. [CrossRef] [PubMed]

91. Zhang, Y.; Jia, F.; Sun, J.R.; Chen, J.L. Cloning and RNA interference analysis of the salivary protein C002 gene in Schizaphis graminum. J. Integr. Agric. 2015, 14, 698-705. [CrossRef]

92. Yu, Y.; Wei, Z. Increased oriental armyworm and aphid resistance in transgenic wheat stably expressing Bacillus thuringiensis (Bt) endotoxin and Pinellia ternate agglutinin (PTA). Plant Cell Tissue Organ 2008, 94, 33-44. [CrossRef]

93. Dutta, I.; Majumder, P.; Saha, P.; Ray, K.; Das, S. Constitutive and phloem specific expression of Allium sativum leaf agglutinin (ASAL) to engineer aphid (Lipaphis erysimi) resistance in transgenic Indian mustard (Brassica juncea). Plant Sci. 2005, 169, 996-1007. [CrossRef]

94. Kanrar, S.; Venkateswari, J.; Kirti, P.; Chopra, V. Transgenic Indian mustard (Brassica juncea) with resistance to the mustard aphid (Lipaphis erysimi Kalt.). Plant Cell Rep. 2002, 20, 976-981.

95. Down, R.E.; Gatehouse, A.M.; Hamilton, W.; Gatehouse, J.A. Snowdrop lectin inhibits development and decrease fecundity of the glasshouse potato aphid (Aulacorthum solani) when administered in vitro and via transgenic plants both in laboratory and glasshouse trials. J. Insect Physiol. 1996, 42, 1035-1045. [CrossRef]

96. Upadhyay, S.K.; Chandrashekar, K.; Thakur, N.; Verma, P.C.; Borgio, J.F.; Singh, P.K.; Tuli, R. RNA interference for the control of whiteflies (Bemisia tabaci) by oral route. J. Biosci. 2011, 36, 153-161. [CrossRef] [PubMed]

97. Li, J.; Li, X.; Bai, R.; Shi, Y.; Tang, Q.; An, S.; Song, Q.; Yan, F. RNA interference of the P450 CYP6CM1 gene has different efficacy in B and Q biotypes of Bemisia tabaci. Pest Manag. Sci. 2015, 71, 1175-1181. [CrossRef] [PubMed]

98. Thakur, N.; Upadhyay, S.K.; Verma, P.C.; Chandrashekar, K.; Tuli, R.; Singh, P. Enhanced whitefly resistance in transgenic tobacco plants expressing double stranded RNA of v-ATPase A gene. PLoS ONE 2014, 9, e87235. [CrossRef] [PubMed] 
99. Raza, A.; Malik, H.J.; Shafiq, M.; Amin, I.; Scheffler, J.A.; Scheffler, B.E.; Mansoor, S. RNA interference based approach to down regulate osmoregulators of whitefly (Bemisia tabaci): Potential technology for the control of whitefly. PLoS ONE 2016, 11, e0153883. [CrossRef] [PubMed]

100. Luan, J.B.; Yao, D.M.; Zhang, T.; Walling, L.L.; Yang, M.; Wang, Y.J.; Liu, S.S. Suppression of terpenoid synthesis in plants by a virus promotes its mutualism with vectors. Ecol. Lett. 2013, 16, 390-398. [CrossRef] [PubMed]

101. Li, J.; Zhu, L.; Hull, J.J.; Liang, S.; Daniell, H.; Jin, S.; Zhang, X. Transcriptome analysis reveals a comprehensive insect resistance response mechanism in cotton to infestation by the phloem feeding insect Bemisia tabaci (whitefly). Plant Biotechnol. J. 2016, 14, 1956-1975. [CrossRef] [PubMed]

102. Liu, S.; Ding, Z.; Zhang, C.; Yang, B.; Liu, Z. Gene knockdown by intro-thoracic injection of double-stranded RNA in the brown planthopper, Nilaparvata lugens. Insect Biochem. Mol. Biol. 2010, 40, 666-671. [CrossRef] [PubMed]

103. Li, J.; Chen, Q.; Lin, Y.; Jiang, T.; Wu, G.; Hua, H. RNA interference in Nilaparvata lugens (Homoptera: Delphacidae) based on dsRNA ingestion. Pest Manag. Sci. 2011, 67, 852-859. [CrossRef] [PubMed]

104. Dong, X.; Zhai, Y.; Zhang, J.; Sun, Z.; Chen, J.; Chen, J.; Zhang, W. Fork head transcription factor is required for ovarian mature in the brown planthopper, Nilaparvata lugens (Stål). BMC Mol. Biol. 2011, 12. [CrossRef] [PubMed]

105. Wu, W.J.; Wang, Y.; Huang, H.J.; Bao, Y.Y.; Zhang, C.X. Ecdysone receptor controls wing morphogenesis and melanization during rice planthopper metamorphosis. J. Insect Physiol. 2012, 58, 420-426. [CrossRef] [PubMed]

106. Ye, M.; Luo, S.M.; Xie, J.F.; Li, Y.F.; Xu, T.; Liu, Y.; Song, Y.Y.; Zhu-Salzman, K.; Zeng, R.S. Silencing COI1 in rice increases susceptibility to chewing insects and impairs inducible defense. PLoS ONE 2012, 7, e36214. [CrossRef] [PubMed]

107. Wang, Y.; Fan, H.W.; Huang, H.J.; Xue, J.; Wu, W.J.; Bao, Y.Y.; Xu, H.J.; Zhu, Z.R.; Cheng, J.A.; Zhang, C.X. Chitin synthase 1 gene and its two alternative splicing variants from two sap-sucking insects, Nilaparvata lugens and Laodelphax striatellus (Hemiptera: Delphacidae). Insect Biochem. Mol. Biol. 2012, 42, 637-646. [CrossRef] [PubMed]

108. Xue, J.; Zhang, X.Q.; Xu, H.J.; Fan, H.W.; Huang, H.J.; Ma, X.F.; Wang, C.Y.; Chen, J.G.; Cheng, J.A.; Zhang, C.X. Molecular characterization of the flightin gene in the wing-dimorphic planthopper, Nilaparvata lugens, and its evolution in Pancrustacea. Insect Biochem. Mol. Biol. 2013, 43, 433-443. [CrossRef] [PubMed]

109. Xu, H.J.; Chen, T.; Ma, X.F.; Xue, J.; Pan, P.L.; Zhang, X.C.; Cheng, J.A.; Zhang, C.X. Genome-wide screening for components of small interfering RNA (siRNA) and micro-RNA (miRNA) pathways in the brown planthopper, Nilaparvata lugens (Hemiptera: Delphacidae). Insect Mol. Biol. 2013, 22, 635-647. [CrossRef] [PubMed]

110. Zhang, X.Y.; Lu, K.; Zhou, J.L.; Zhou, Q. Molecular characterization and gene functional analysis of Dicer-2 gene from Nilaparvata lugens (Hemiptera: Geometroidea). Insect Sci. 2013, 20, 61-68. [CrossRef] [PubMed]

111. Zhai, Y.; Zhang, J.; Sun, Z.; Dong, X.; He, Y.; Kang, K.; Liu, Z.; Zhang, W. Proteomic and transcriptomic analyses of fecundity in the brown planthopper Nilaparvata lugens (Stal). J. Proteome Res. 2013, 12, 5199-5212. [CrossRef] [PubMed]

112. Zhang, X.; Lu, K.; Zhou, Q. Dicer1 is crucial for the oocyte maturation of telotrophic ovary in Nilaparvata lugens (STÅL) (Hemiptera: Geometroidea). Arch. Insect Biochem. Physiol. 2013, 84, 194-208. [CrossRef] [PubMed]

113. Ge, L.Q.; Huang, L.J.; Yang, G.Q.; Song, Q.S.; Stanley, D.; Gurr, G.M.; Wu, J.C. Molecular basis for insecticide-enhanced thermotolerance in the brown planthopper Nilaparvata lugens Stål (Hemiptera: Delphacidae). Mol. Ecol. 2013, 22, 5624-5634. [CrossRef] [PubMed]

114. Zhou, W.W.; Liang, Q.M.; Xu, Y.; Gurr, G.M.; Bao, Y.Y.; Zhou, X.P.; Zhang, C.X.; Cheng, J.; Zhu, Z.R. Genomic insights into the glutathione s-transferase gene family of two rice planthoppers, Nilaparvata lugens (Stål) and Sogatella furcifera (Horváth) (Hemiptera: Delphacidae). PLoS ONE 2013, 8, e56604. [CrossRef] [PubMed]

115. Yu, R.; Xu, X.; Liang, Y.; Tian, H.; Pan, Z.; Jin, S.; Wang, N.; Zhang, W. The insect ecdysone receptor is a good potential target for RNAi-based pest control. Int. J. Biol. Sci. 2014, 10, 1171-1180. [CrossRef] [PubMed]

116. Lu, K.; Shu, Y.; Zhou, J.; Zhang, X.; Zhang, X.; Chen, M.; Yao, Q.; Zhou, Q.; Zhang, W. Molecular characterization and RNA interference analysis of vitellogenin receptor from Nilaparvata lugens (Stål). J. Insect Physiol. 2015, 73, 20-29. [CrossRef] [PubMed] 
117. Wang, W.X.; Li, K.L.; Chen, Y.; Lai, F.X.; Fu, Q. Identification and function analysis of enolase gene NIEno1 from Nilaparvata lugens (Stål) (Hemiptera: Delphacidae). J. Insect Sci. 2015, 15. [CrossRef] [PubMed]

118. Zhang, B.X.; Huang, H.J.; Yu, B.; Lou, Y.H.; Fan, H.W.; Zhang, C.X. Bicaudal-C plays a vital role in oogenesis in Nilaparvata lugens (Hemiptera: Delphacidae). J. Insect Physiol. 2015, 79, 19-26. [CrossRef] [PubMed]

119. Liu, Z.Y.; Jiang, Y.P.; Li, L.; You, L.L.; Wu, Y.; Xu, B.; Ge, L.Q.; Wu, J.C. Silencing of ACO decreases reproduction and energy metabolism in triazophos-treated female brown plant hoppers, Nilaparvata lugens Stål (Hemiptera: Delphacidae). Pest Biochem. Physiol. 2015, 128, 76-81. [CrossRef] [PubMed]

120. Zhang, Y.X.; Ge, L.Q.; Jiang, Y.P.; Lu, X.L.; Li, X.; Stanley, D.; Song, Q.S.; Wu, J.C. RNAi knockdown of acetyl-CoA carboxylase gene eliminates jinggangmycin-enhanced reproduction and population growth in the brown planthopper, Nilaparvata lugens. Sci. Rep. 2015, 5. [CrossRef] [PubMed]

121. Zhai, Y.; Sun, Z.; Zhang, J.; Kang, K.; Chen, J.; Zhang, W. Activation of the TOR signalling pathway by glutamine regulates insect fecundity. Sci. Rep. 2015, 5. [CrossRef] [PubMed]

122. Lu, K.; Chen, X.; Liu, W.; Zhou, Q. Identification of a heat shock protein 90 gene involved in resistance to temperature stress in two wing-morphs of Nilaparvata lugens (Stål). Comp. Biochem. Phys. A 2016, 197, 1-8. [CrossRef] [PubMed]

123. Xi, Y.; Pan, P.L.; Zhang, C.X. The $\beta$-N-acetylhexosaminidase gene family in the brown planthopper, Nilaparvata lugens. Insect Mol. Biol. 2015, 24, 601-610. [CrossRef] [PubMed]

124. Yang, M.; Zhao, L.; Shen, Q.; Xie, G.; Wang, S.; Tang, B. Knockdown of two trehalose-6-phosphate synthases severely affects chitin metabolism gene expression in the brown planthopper Nilaparvata lugens. Pest Manag. Sci. 2016. [CrossRef] [PubMed]

125. Lu, K.; Chen, X.; Liu, W.T.; Zhang, X.Y.; Chen, M.X.; Zhou, Q. Nutritional signaling regulates vitellogenin synthesis and egg development through juvenile hormone in Nilaparvata lugens (Stål). Int. J. Mol. Sci. 2016, 17. [CrossRef] [PubMed]

126. Lu, K.; Chen, X.; Liu, W.T.; Zhou, Q. TOR pathway-mediated juvenile hormone synthesis regulates nutrient-dependent female reproduction in Nilaparvata lugens (Stål). Int. J. Mol. Sci. 2016, 17. [CrossRef] [PubMed]

127. Bao, H.; Gao, H.; Zhang, Y.; Fan, D.; Fang, J.; Liu, Z. The roles of CYP6AY1 and CYP6ER1 in imidacloprid resistance in the brown planthopper: Expression levels and detoxification efficiency. Pest Biochem. Physiol. 2015, 129, 70-74. [CrossRef] [PubMed]

128. Lu, D.H.; Wu, M.; Pu, J.; Feng, A.; Zhang, Q.; Han, Z.J. A functional study of two dsRNA binding protein genes in Laodelphax striatellus. Pest Manag. Sci. 2013, 69, 1034-1039. [CrossRef] [PubMed]

129. Wan, P.J.; Jia, S.; Li, N.; Fan, J.M.; Li, G.Q. RNA interference depletion of the halloween gene Disembodied implies its potential application for management of planthopper Sogatella furcifera and Laodelphax striatellus. PLOS ONE 2014, 9, e86675. [CrossRef] [PubMed]

130. Elzaki, M.E.A.; Zhang, W.; Feng, A.; Qiou, X.; Zhao, W.; Han, Z. Constitutive overexpression of cytochrome P450 associated with imidacloprid resistance in Laodelphax striatellus (Fallén). Pest Manag. Sci. 2016, 72, 1051-1058. [CrossRef] [PubMed]

131. Xu, Y.; Huang, L.; Wang, Z.; Fu, S.; Che, J.; Qian, Y.; Zhou, X. Identification of Himetobi P virus in the small brown planthopper by deep sequencing and assembly of virus-derived small interfering RNAs. Virus Res. 2014, 179, 235-240. [CrossRef] [PubMed]

132. Liu, W.; Gray, S.; Huo, Y.; Li, L.; Wei, T.; Wang, X. Proteomic analysis of interaction between a plant virus and its vector insect reveals new functions of hemipteran cuticular protein. Mol. Cell Proteom. 2015, 14, 2229-2242. [CrossRef] [PubMed]

133. Yu, J.L.; An, Z.F.; Liu, X.D. Wingless gene cloning and its role in manipulating the wing dimorphism in the white-backed planthopper, Sogatella furcifera. BMC Mol. Biol. 2014, 15. [CrossRef] [PubMed]

134. Yang, Y.; Wan, P.J.; Hu, X.X.; Li, G.Q. RNAi mediated knockdown of the ryanodine receptor gene decreases chlorantraniliprole susceptibility in Sogatella furcifera. Pest Biochem. Physiol. 2014, 108, 58-65. [CrossRef] [PubMed]

135. Jia, S.; Wan, P.J.; Zhou, L.T.; Mu, L.L.; Li, G.Q. Molecular cloning and RNA interference-mediated functional characterization of a Halloween gene spook in the white-backed planthopper Sogatella furcifera. BMC Mol. Biol. 2013, 14. [CrossRef] [PubMed] 
136. Jia, D.; Mao, Q.; Chen, H.; Wang, A.; Liu, Y.; Wang, H.; Xie, L.; Wei, T. Virus-induced tubule: A vehicle for rapid spread of virions through basal lamina from midgut epithelium in the insect vector. J. Virol. 2014, 88, 10488-10500. [CrossRef] [PubMed]

137. Matsumoto, Y.; Hattori, M. Gene silencing by parental RNA interference in the green rice leafhopper, Nephotettix cincticeps (Hemiptera: Cicadellidae). Arch. Insect Biochem. Physiol. 2016, 91, 152-164. [CrossRef] [PubMed]

138. Chen, Q.; Chen, H.; Mao, Q.; Liu, Q.; Shimizu, T.; Uehara-Ichiki, T.; Wu, Z.; Xie, L.; Omura, T.; Wei, T. Tubular structure induced by a plant virus facilitates viral spread in its vector insect. PLoS Pathog. 2012, 8, e1003032. [CrossRef] [PubMed]

139. Chen, Q.; Zhang, L.; Chen, H.; Xie, L.; Wei, T. Nonstructural protein Pns4 of rice dwarf virus is essential for viral infection in its insect vector. Virol. J. 2015, 12. [CrossRef] [PubMed]

140. Chen, Y.; Cassone, B.J.; Bai, X.; Redinbaugh, M.G.; Michel, A.P. Transcriptome of the plant virus vector Graminella nigrifrons, and the molecular interactions of Maize fine streak rhabdovirus transmission. PLoS ONE 2012, 7, e40613. [CrossRef] [PubMed]

141. Chen, Y.; Redinbaugh, M.G.; Michel, A.P. Molecular interactions and immune responses between Maize fine streak virus and the leafhopper vector Graminella nigrifrons through differential expression and RNA interference. Insect Mol. Biol. 2015, 24, 391-401. [CrossRef] [PubMed]

142. Eliautout, R.; Dubrana, M.P.; Vincent-Monégat, C.; Vallier, A.; Braquart-Varnier, C.; Poirié, M.; Saillard, C.; Heddi, A.; Arricau-Bouvery, N. Immune response and survival of Circulifer haematoceps to Spiroplasma citri infection requires expression of the gene hexamerin. Dev. Comp. Immunol. 2016, 54, 7-19. [CrossRef] [PubMed]

143. Badillo-Vargas, I.E.; Rotenberg, D.; Schneweis, B.A.; Whitfield, A.E. RNA interference tools for the western flower thrips, Frankliniella occidentalis. J. Insect Physiol. 2015, 76, 36-46. [CrossRef] [PubMed]

144. Whitten, M.M.; Facey, P.D.; del Sol, R.; Fernández-Martínez, L.T.; Evans, M.C.; Mitchell, J.J.; Bodger, O.G.; Dyson, P.J. Symbiont-mediated RNA interference in insects. Proc. R. Soc. B 2016, 283. [CrossRef] [PubMed]

145. Alves, A.P.; Lorenzen, M.D.; Beeman, R.W.; Foster, J.E.; Siegfried, B.D. RNA Interference as a method for target-site screening in the western corn rootworm, Diabrotica Virgifera Virgifera. J. Insect Sci. 2010, 10. [CrossRef] [PubMed]

146. Ramaseshadri, P.; Segers, G.; Flannagan, R.; Wiggins, E.; Clinton, W.; Ilagan, O.; McNulty, B.; Clark, T.; Bolognesi, R. Physiological and cellular responses caused by RNAi-mediated suppression of Snf7 orthologue in western corn rootworm (Diabrotica virgifera virgifera) Larvae. PLoS ONE 2013, 8, e54270. [CrossRef] [PubMed]

147. Rangasamy, M.; Siegfried, B.D. Validation of RNA interference in western corn rootworm Diabrotica virgifera virgifera LeConte (Coleoptera: Chrysomelidae) adults. Pest Manag. Sci. 2012, 68, 587-591. [CrossRef] [PubMed]

148. Chu, C.C.; Sun, W.; Spencer, J.L.; Pittendrigh, B.R.; Seufferheld, M.J. Differential effects of RNAi treatments on field populations of the western corn rootworm. Pest Biochem. Physiol. 2014, 110, 1-6. [CrossRef] [PubMed]

149. Khajuria, C.; Vélez, A.M.; Rangasamy, M.; Wang, H.; Fishilevich, E.; Frey, M.L.; Carneiro, N.P.; Gandra, P.; Narva, K.E.; Siegfried, B.D. Parental RNA interference of genes involved in embryonic development of the western corn rootworm, Diabrotica virgifera virgifera LeConte. Insect Biochem. Mol. Biol. 2015, 63, 54-62. [CrossRef] [PubMed]

150. Fishilevich, E.; Vélez, A.M.; Khajuria, C.; Frey, M.L.; Hamm, R.L.; Wang, H.; Schulenberg, G.A.; Bowling, A.J.; Pence, H.E.; Gandra, P.; et al. Use of chromatin remodeling ATPases as RNAi targets for parental control of western corn rootworm (Diabrotica virgifera virgifera) and Neotropical brown stink bug (Euschistus heros). Insect Biochem. Mol. Biol. 2016, 71, 58-71. [CrossRef] [PubMed]

151. Coleman, A.D.; Wouters, R.H.; Mugford, S.T.; Hogenhout, S.A. Persistence and transgenerational effect of plant-mediated RNAi in aphids. J. Exp. Bot. 2015, 66, 541-548. [CrossRef] [PubMed]

152. Jin, S.; Zhang, X.; Daniell, H. Pinellia ternata agglutinin expression in chloroplasts confers broad spectrum resistance against aphid, whitefly, lepidopteran insects, bacterial and viral pathogens. Plant Biotechnol. J. 2012, 10, 313-327. [CrossRef] [PubMed]

153. Ebert, T.A.; Cartwright, B. Biology and ecology of Aphis gossypii Glover (Homoptera: Aphididae). Southwest Entomol. 1997, 22, 116-153. 
154. Gray, S.M. Intraspecific variability of luteovirus transmission within aphid vector populations. In The Luteoviridae; Smith, H.G., Barker, H., Eds.; CABI Publishing: Wallingford, UK, 1999.

155. Wang, R.Y.; Powell, G.; Hardie, J.; Pirone, T.P. Role of the helper component in vector-specific transmission of potyviruses. J. Gen. Virol. 1998, 79, 1519-1524. [CrossRef] [PubMed]

156. Mikoshiba, Y.; Honda, K.; Kanematsu, S.; Fujisawa, I. Distribution of Soybean Dwarf Virus Strainsin Japan. Ann. Phytopathol. Soc. Jpn. 1995, 61, 276.

157. Jones, D.R. Plant viruses transmitted by whiteflies. Eur. J. Plant Pathol. 2003, 109, 195-219. [CrossRef]

158. King, A.M.; Adams, M.J.; Lefkowitz, E.J. Virus Taxonomy: Classification and Nomenclature of Viruses: Ninth Report of the International Committee on Taxonomy of Viruses; Elsevier Academic Press: London, UK; San Diego, CA, USA, 2012.

159. Preap, V.; Zalucki, M.P.; Jahn, G.C. Brown planthopper outbreaks and management. Cambodian J. Agric. 2006, 7, 17-25.

160. Jia, S.; Wan, P.J.; Zhou, L.T.; Mu, L.L.; Li, G.Q. Knockdown of a putative halloween gene shade reveals its role in ecdysteroidogenesis in the small brown planthopper Laodelphax striatellus. Gene 2013, 531, 168-174. [CrossRef] [PubMed]

161. Wan, P.J.; Jia, S.; Li, N.; Fan, J.M.; Li, G.Q. The putative Halloween gene phantom involved in ecdysteroidogenesis in the white-backed planthopper Sogatella furcifera. Gene 2014, 548, 112-118. [CrossRef] [PubMed]

162. Nault, L.R.; Styer, W.E.; Coffey, M.E.; Gordon, D.T.; Negi, L.S.; Niblett, C.L. Transmission of maize chlorotic mottle virus by chrysomelid beetles. Phytopathology 1978, 68, 1071-1074. [CrossRef]

163. Oliveira, V.C.; Bartasson, L.; de Castro, M.E.B.; Corrêa, J.R.; Ribeiro, B.M.; Resende, R.O. A silencing suppressor protein (NSs) of a tospovirus enhances baculovirus replication in permissive and semipermissive insect cell lines. Virus Res. 2011, 155, 259-267. [CrossRef] [PubMed]

164. Ohnesorge, S.; Bejarano, E.R. Begomovirus coat protein interacts with a small heat-shock protein of its transmission vector (Bemisia tabaci). Insect Mol. Biol. 2009, 18, 693-703. [CrossRef] [PubMed]

165. Götz, M.; Popovski, S.; Kollenberg, M.; Gorovits, R.; Brown, J.K.; Cicero, J.M.; Czosnek, H.; Winter, S.; Ghanim, M. Implication of Bemisia tabaci heat shock protein 70 in begomovirus-whitefly interactions. J. Virol. 2012, 86, 13241-13252. [CrossRef] [PubMed]

166. De Paula, N.T.; de Faria, J.C.; Aragão, F.J. Reduction of viral load in whitefly (Bemisia tabaci Gen.) feeding on RNAi-mediated bean golden mosaic virus resistant transgenic bean plants. Virus Res. 2015, 210, $245-247$. [CrossRef] [PubMed]

(C) 2016 by the authors; licensee MDPI, Basel, Switzerland. This article is an open access article distributed under the terms and conditions of the Creative Commons Attribution (CC-BY) license (http://creativecommons.org/licenses/by/4.0/). 